National Marine

Fisheries Service

NOAA
Fishery Bulletin

a established in 1881 a
Spencer F. Baird

First U.S. Commissione of Fisheries and founder of Fishery Bulletin
Abstract-The blue shark (Prionace glauca) is the most landed shark species in Peruvian shark fisheries, representing $42 \%$ of total landings. Despite its importance for fisheries, the ecological role of the blue shark in Peruvian waters remains poorly understood. Therefore, in this study, we aimed to assess the food habits of blue sharks off northern Peru through stomach content analysis. Between February and December of 2015, 143 stomachs were collected and 28 found to be were empty. Individuals measured from 110.0 to $299.4 \mathrm{~cm}$ in total length. The results indicate that blue sharks have epipelagic and mesobathypelagic feeding habits, preying upon a wide number of prey taxa (42 species) but with a diet dominated by cephalopods, especially Argonauta spp. and Ancistrocheirus lesueurii. Diets differed by size class and location, suggesting that longitudinal movements are related to increments in body size. In addition, we propose that blue sharks scavenge for food on the basis of finding the cyprid larval stage and juvenile cosmopolitan duck barnacle (Lepas anatifera) associated with the prey item 'unidentified cephalopods.' The present study contributes new information on the diet of blue sharks.

Manuscript submitted 14 December 2017. Manuscript accepted 16 August 2018.

Fish. Bull. 116:310-322 (2018).

Online publication date: 11 September 2018. doi: 10.7755/FB.116.3-4.9

The views and opinions expressed or implied in this article are those of the author (or authors) and do not necessarily reflect the position of the National Marine Fisheries Service, NOAA.

\title{
Food habits of the blue shark, Prionace glauca (Linnaeus, 1758), in waters off northern Peru
}

\author{
Francisco Córdova-Zavaleta (contact author) ${ }^{1,2}$ \\ Jaime Mendo ${ }^{2}$ \\ Sergio A. Briones-Hernández ${ }^{3}$ \\ Nicolas Acuña-Perales ${ }^{1}$ \\ Adriana Gonzalez-Pestana ${ }^{1,4}$ \\ Joanna Alfaro-Shigueto 1,4,5 \\ Jeffrey C. Mangel ${ }^{1,5}$
}

Email address for contact author: fcordova@prodelphinus.org

1 ProDelphinus

Calle Jose Galvez 780-e

15074 Lima, Peru

2 Facultad de Pesquería

Universidad Nacional Agraria la Molina

Avenida La Molina s/n

15024 Lima, Peru

${ }^{3}$ Centro Interdisciplinario de Ciencias Marinas Instituto Politécnico Nacional

Avenida Instituto Politécnico Nacional s/n

Colonia Playa Palo de Santa Rita Apdo.

23096 La Paz, Baja California Sur, Mexico

\author{
${ }^{4}$ Facultad de Biología Marina \\ Universidad Científica del Sur \\ Panamericana Sur Km 19 \\ 15067 Lima, Peru \\ ${ }^{5}$ Center for Ecology and Conservation \\ College of Life and Environmental Sciences \\ University of Exeter, Penryn Campus \\ Penryn, Cornwall TR10 9FE, United Kingdom
}

In the southeastern Pacific Ocean, the area off northern Peru is an important area of convergence between temperate (Humboldt Current) and tropical (South Equatorial Current) waters (Spalding et al., 2007). This particular area hosts a diversity of marine species (Chirichigno and Cornejo, 2001), including a large number of sharks (Cornejo et al., 2015). One of these is the blue shark (Prionace glauca), which is considered a key cosmopolitan pelagic species that exerts topdown control on community structure (Stevens et al., 2000).

On a global scale, the blue shark is the most landed shark species (as target and nontarget catch) and the major component of the international shark fin trade (Clarke et al., 2006; Nakano and Stevens, 2008). It is also the most landed species by Peruvian shark fisheries, representing $42 \%$ of total landings (Gonzalez-Pestana et al.,1 2016). Seventy percent of blue shark landings come from the smallscale longline fishery operating along the coast (Doherty et al., 2014), especially off southern Peru where cold to temperate waters support higher abundances of pelagic sharks (Adams et al., 2016). Likewise, it is one of the most frequently species caught in Peruvian small-scale driftnet shark fisheries (Alfaro-Shigueto et al., 2010). However, despite its importance for fisheries, biological studies describing the ecological role of blue sharks in Peruvian waters are few.

There have been several studies regarding the diet of blue sharks in

${ }^{1}$ Gonzalez-Pestana, A., C. Kouri, and X. Velez-Zuazo. In review. Shark fisheries in the southeast Pacific: a 61-year analysis from Peru. F1000Research 3:164. [Available at website.] 


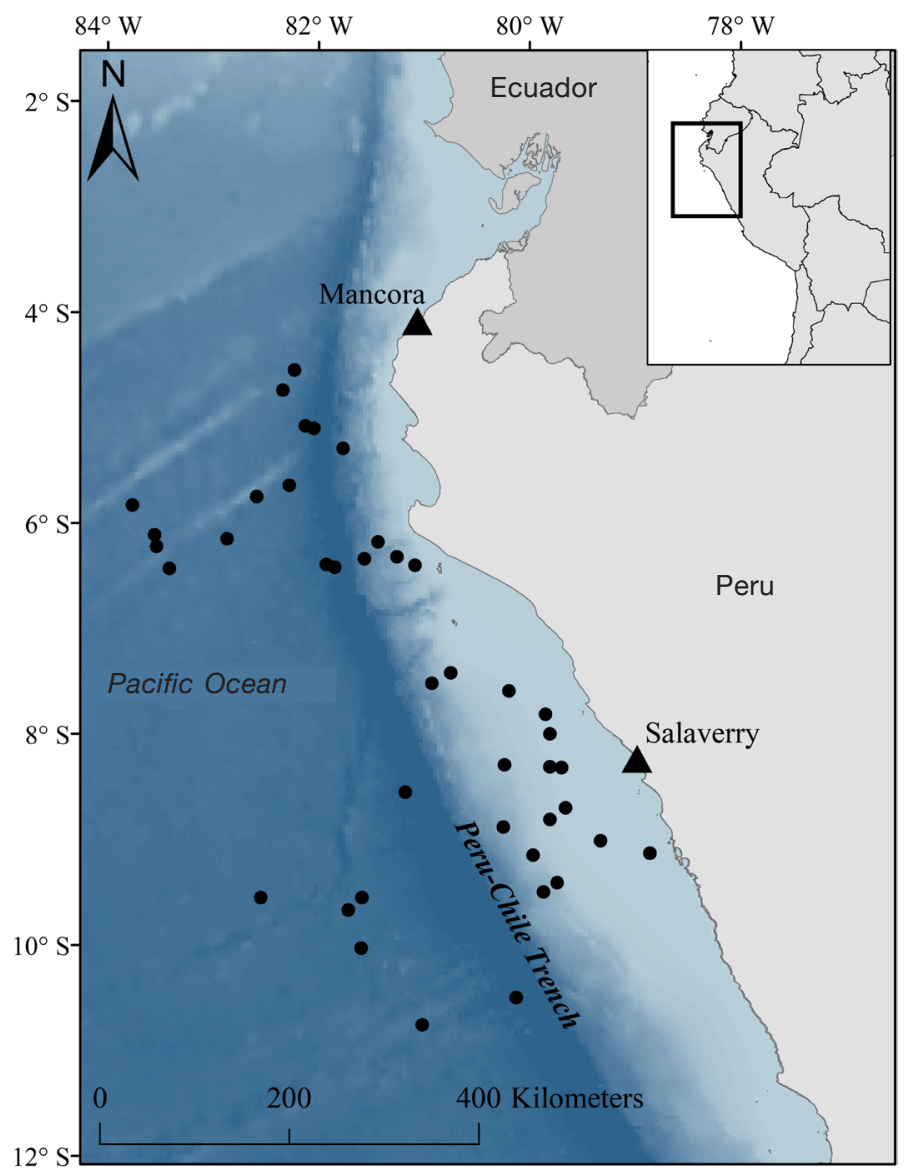

Figure 1

Map of locations where blue sharks (Prionace glauca) were collected in northern Peru between February and December 2015. The blue vertical gradient defines the position of the Peru-Chile Trench (with an average distance from shore of $130 \mathrm{~km}$ or 70 nautical miles).

the eastern Pacific Ocean. For example, Tricas (1979) and Harvey (1989) reported that blue sharks consume euphausiids (mostly Thysanoessa spinifera), small fish (e.g., the northern anchovy, Engraulis mordax), and a variety of cephalopods (e.g., Loliginidae and Histioteuthidae). Studies from the Mexican Pacific Ocean have revealed a high consumption of the pelagic red crab (Pleuroncodes planipes), as well as a variety of squid, including Histioteuthis heteropsis, Gonatus californiensis, and Ancistrocheirus lesueurii (Markaida and Sosa-Nishizaki, 2010; Hernández-Aguilar et al., 2016). Loor-Andrade et al. (2017) showed that A. lesueurii, Stigmatoteuthis hoylei, and the jumbo squid (Dosidicus gigas) were the most consumed species off Ecuador. In Chilean waters, prey species included a variety of fishes: mackerels (Trachurus murphyi and the Pacific chub mackerel, Scomber japonicus) and tunas (Thunnus spp.), as well as jumbo squid (Lopez et al., 2010; Klarian et al., 2018).

In Peru, three studies of blue shark diet have revealed that they feed on jumbo squid, Peruvian anchoveta (Engraulis ringens), Pacific sardine (Sardinops sagax), Peruvian hake (Merluccius gayi peruanus), and eggs from flying fish (Exocoetidae) and Chilean silverside (Odontesthes regia) (Hoyos et al., 1991; Elliot et al., 1995, 1996). Although these previous studies provide valuable insights into prey species of blue sharks off the coast of Peru, their results have been limited by sample size, time series, and size classes. Therefore, to determine the ecological role of blue sharks in the Peruvian marine ecosystem, we focused on providing broader information on blue shark food habits off northern Peru by analyzing stomach contents and assessing diet variability by sex, size class, season, and fishing ground.

\section{Materials and methods}

\section{Sampling and stomach content analysis}

Stomach contents of blue sharks were collected between February and December 2015 by onboard observers during small-scale driftnet and longline fishing trips that landed in Mancora and Salaverry ports in northern Peru (Fig. 1). Sex of each shark was determined and total length (TL) was measured to the nearest centimeter (Bigelow and Schroeder, 1948). Stomachs were extracted and preserved in $10 \%$ formalin for analysis (Galván-Magaña et al., 1989). Stomach samples were examined at the Laboratorio de Recursos Hidrobiológicos of the Universidad Nacional Agraria la Molina, where prey items were identified to the lowest possible taxon and weighed (wet weight) to the nearest 0.01 g. Fish items (entire specimens and skeletons) were identified according to Chirichigno and Velez (1998) and Clothier (1950), and fish otoliths were identified according to Rivaton and Bourret (1999) and García-Godos (2001). Cephalopods were identified by examination of beaks (Wolff, 1982, 1984; Clarke, 1986; Xavier and Cherel, 2009). Crustaceans and marine mammals were identified according to Moscoso (2013) and Jefferson et al. (2015), respectively. Reconstruction of cephalopod weights by regression equations was based on measurements of the lower rostral length of cephalopod beaks (Wolff, 1982, 1984; Clarke, 1986; Smale et al., 1993; Xavier and Cherel, 2009), whereas reconstruction of fish weights was based on the relationship of length to weight (Fernández, 1987; IMARPE $^{2}$ ) and the relationship of otolith radius to total length (Goicochea and Arrieta, 2008) when possible.

To assess whether the sample size collected was appropriate to describe the diet of blue sharks, we constructed a cumulative prey curve at the family level from the total number of prey species identified, excluding 'unidentified remains' (i.e., cephalopod, fish, and crustacean) prey items by using the software Es-

\footnotetext{
2 IMARPE (Instituto del Mar del Peru). 2012. Crucero 120204 de "Evaluación hidroacústica de los recursos pelágicos." Inst. Mar Peru, Inf. Ejec., 49 p. [Available from website.]
} 
timateS, vers. 9.1.0 (Colwell, 2013). The order of samples was permuted 1000 times to reduce bias. Following the method of Jiménez-Valverde and Hortal (2003), we plotted the results to analyze the suitability of the sample size. When the curve approaches the asymptote $($ slope $<0.1)$, the number of samples is deemed to be sufficient to describe the diet (Soberón and Llorente, 1993). Furthermore, we used the calculation method proposed by Bizzarro et al. (2007) to reinforce the sampling assessment. This method states that the slope of the line generated from the curve endpoints (mean cumulative number of prey taxa generated for the final 4 stomach samples) should be compared to a line of 0 slope to establish whether a cumulative prey curve has reached an asymptote. Slopes are compared by using Student's $t$-test, where slopes that are not significant $(P>0.05)$ indicate that the curve has reached an asymptote (Bizzarro et al., 2007).

The relative importance of each prey species to the diet of the blue shark was established by the prey-specific index of relative importance (\%PSIRI) (Brown et al., 2012), by using the equation:

$$
\% P S I R I=0.5 \% F O_{\mathrm{i}} \times\left(\% P N_{\mathrm{i}}+\% P W_{\mathrm{i}}\right),
$$

where $\% F O_{\mathrm{i}}=$ the number of stomachs containing prey category $i$, divided by the total number of stomachs $n$;

$\% P N_{\mathrm{i}}=$ prey-specific numeric abundance; and

$\% P W_{\mathrm{i}}=$ prey-specific wet-weight abundance.

Prey-specific abundance $\left(\% P A_{\mathrm{i}}\right)$ was calculated by

$$
\% P A_{\mathrm{i}}=\Sigma_{\mathrm{j}=1}^{\mathrm{n}} \% A_{\mathrm{ij}} n_{\mathrm{i}}^{-1},
$$

where $\% A_{\mathrm{ij}}=$ the abundance $\left(\right.$ by counts $\left[\% P N_{\mathrm{i}}\right]$ or weight $\left.\left[\% P W_{\mathrm{i}}\right]\right)$ of prey category $i$ in stomach sample $j$; and

$n_{\mathrm{i}}=$ the number of stomachs containing prey $i$.

The \%PSIRI, is a modification of the index of relative importance (\%IRI [Cortés, 1997]) that avoids \%FO redundancies taken in the \%IRI and is additive with respect to taxonomic levels. As a result, the \%PSIRI of a family will be equal to the sum of the \%PSIRI of the species within the taxon (Brown et al., 2012).

Niche breadth was calculated according to Levin's standardized index by using \%PSIRI converted to proportions at the family level (Krebs, 1999). The index values ranged between 0 and 1 , where values closer to 0 indicate a diet dominated by few prey species (i.e., by a greater degree of specialization) and values closer to 1 indicate a lesser degree of specialization (Munroe et al., 2014). In addition, the graphical analysis proposed by Amundsen et al. (1996) was performed to explore prey importance at the family level and predator feeding strategy. The analysis is based on a 2 -dimensional graph representation of prey-specific abundance $\left(\% P A_{\mathrm{i}}\right)$ in relation to the frequency of occurrence of the different prey types in the $\operatorname{diet}\left(\% F O_{\mathrm{i}}\right)$.

Trophic position was calculated based on percent weight values of the prey species identified with the equation proposed by Christensen and Pauly (1992):

$$
T P=1+\left(\Sigma_{\mathrm{j}=1}^{\mathrm{n}} D C_{\mathrm{ij}}\right) \times\left(T P_{\mathrm{j}}\right),
$$

where $D C_{\mathrm{ij}}=$ the composition of the prey $j$ in the diet of the predator $I$;

$T P_{\mathrm{j}}=$ to the trophic level of prey $j$; and

$n=$ the number of prey species in the diet of predator $j$.

Values of trophic position for fish prey were obtained from Froese and Pauly ${ }^{3}$ and Espinoza (2014); and for cephalopod prey from Cortés (1999) and Espinoza (2014).

To identify possible differences in diet, individual sharks were analyzed according to 5 factors: sex, season, size class, latitude of fishing ground, and longitude of fishing ground. The analysis by sex was performed to clarify whether the composition of diets of females and males is related to the reported spatial segregation by sex (Nakano and Stevens, 2008). Specimens analyzed per season were grouped into warm (FebruaryMay and December) and cold (June-November) seasons according to established patterns of sea-surface temperatures (SST) (Flores et al., 2013). Cluster analysis was employed with 20-, 30-, and 40-cm-TL intervals to define size classes (Markaida and Sosa-Nishizaki, 2010) by using the numeric abundance (at family levels) of identified preys. Calculations were performed by the unweighted pair-group method with arithmetic mean and by using the Bray-Curtis index as a measure of dissimilarity. A $50 \%$ of dissimilarity distance indicated major divisions between size classes (Ebert and Bizzarro, 2007). Fishing grounds based on latitude were grouped into 2 biogeographical marine provinces, where 'northern' corresponds to the Tropical Eastern Pacific marine province and 'Northern-Central' to the Warm Temperate Southeastern Pacific marine province (Spalding et al., 2007). Fishing grounds based on longitude were grouped into 'coastal' and 'oceanic' groups, with the Peru-Chile Trench (which occurs at an average distance from the coast of $130 \mathrm{~km}$ or 70 nautical miles) as the boundary between these 2 groups (Macharé et al., 1986) (Fig. 1).

\section{Statistical analysis}

To assess differences in the diet of blue sharks by factors, we performed two multivariate techniques: nonmetric multidimensional scaling (MDS) ordinations and analysis of similarity (ANOSIM). These techniques were conducted with the Bray-Curtis index of dissimilarity generated from the numeric abundance of each prey grouped by family (Mendoza-Ávila et al., 2016), pretreated by fourth-root transformation and standardized to percentages. The stress value generated by the nonmetric MDS model indicates the reliability of the representation, where values closer to 0 indicate excellent representation and values larger than 0.2 indicate that interpretation of the data is unreliable (Clarke,

\footnotetext{
${ }^{3}$ Froese, R., and D. Pauly (eds.). 2018. FishBase, vers. 02/2018. World Wide Web electronic publication. [Available from website.]
} 


\section{Table 1}

Diet composition of blue sharks (Prionace glauca), based on analysis of stomach contents collected between February and December 2015 off northern Peru, by percent frequency of occurrence (\%FO), percent prey-specific number $(\% \mathrm{PN})$, percent number $(\% \mathrm{~N})$, percent prey-specific weight $(\% \mathrm{PW})$, percent weight $(\% \mathrm{~W})$ and the prey-specific index of relative importance (\%PSIRI).

\begin{tabular}{|c|c|c|c|c|c|c|}
\hline Prey species & $\% \mathrm{FO}$ & $\% \mathrm{~N}$ & $\% \mathrm{PN}$ & $\% \mathrm{~W}$ & $\% \mathrm{PW}$ & $\%$ PSIRI \\
\hline \multicolumn{7}{|l|}{ CEPHALOPODA } \\
\hline \multicolumn{7}{|l|}{ Decapodiformes } \\
\hline Oegopsida & 4.35 & 0.27 & 6.18 & $<0.01$ & $<0.01$ & 0.13 \\
\hline \multicolumn{7}{|l|}{ Ancistrocheiridae } \\
\hline Ancistrocheirus lesueurii & 14.78 & 5.07 & 34.31 & 7.37 & 49.86 & 6.22 \\
\hline \multicolumn{7}{|l|}{ Chiroteuthidae } \\
\hline Chiroteuthis veranyi & 3.48 & 1.45 & 41.83 & 0.93 & 26.85 & 1.19 \\
\hline Grimalditeuthis bonplandi & 11.30 & 1.88 & 16.66 & $<0.01$ & $<0.01$ & 0.94 \\
\hline \multicolumn{7}{|l|}{ Cranchiidae } \\
\hline Galiteuthis pacifica & 2.61 & 1.14 & 43.63 & 0.88 & 33.55 & 1.01 \\
\hline Leachia danae & 4.35 & 1.06 & 24.34 & 0.24 & 5.42 & 0.65 \\
\hline \multicolumn{7}{|l|}{ Enoploteuthidae } \\
\hline Abraliopsis affinis & 1.74 & 0.51 & 29.35 & 0.28 & 16.34 & 0.40 \\
\hline \multicolumn{7}{|l|}{ Gonatidae } \\
\hline Gonatus antarcticus & 11.30 & 4.06 & 35.90 & 5.88 & 51.98 & 4.97 \\
\hline Gonatus sp. & 0.87 & 0.87 & 100.00 & 0.87 & 100.00 & 0.87 \\
\hline \multicolumn{7}{|l|}{ Histioteuthidae } \\
\hline Histioteuthis cerasina & 0.87 & 0.14 & 16.67 & 0.05 & 6.00 & 0.10 \\
\hline Stigmatoteuthis hoylei & 6.96 & 2.12 & 30.44 & 2.91 & 41.83 & 2.51 \\
\hline \multicolumn{7}{|l|}{ Mastigoteuthidae } \\
\hline Mastigoteuthis dentata & 2.61 & 1.53 & 58.59 & 0.88 & 33.64 & 1.20 \\
\hline \multicolumn{7}{|l|}{ Octopoteuthidae } \\
\hline Octopoteuthis sicula & 6.09 & 1.65 & 27.15 & 1.30 & 21.35 & 1.48 \\
\hline \multicolumn{7}{|l|}{ Ommastrephidae } \\
\hline Dosidicus gigas & 6.09 & 1.58 & 26.03 & 4.03 & 66.17 & 2.81 \\
\hline Ommastrephes bartramii & 1.74 & 0.61 & 35.00 & 1.22 & 70.40 & 0.92 \\
\hline \multicolumn{7}{|l|}{ Onychoteuthidae } \\
\hline Onychoteuthis banksii & 4.35 & 0.89 & 20.46 & 0.07 & 1.72 & 0.48 \\
\hline \multicolumn{7}{|l|}{ Pholidoteuthidae } \\
\hline Pholidoteuthis massyae & 3.48 & 0.27 & 7.74 & 0.11 & 3.05 & 0.19 \\
\hline \multicolumn{7}{|l|}{ Thysanoteuthidae } \\
\hline Thysanoteuthis rhombus & 12.17 & 5.53 & 45.41 & 6.43 & 52.79 & 5.98 \\
\hline \multicolumn{7}{|l|}{ Myopsida } \\
\hline \multicolumn{7}{|l|}{ Loliginidae } \\
\hline Doryteuthis (Amerigo) gahi & 2.61 & 0.49 & 18.88 & 1.39 & 53.43 & 0.94 \\
\hline \multicolumn{7}{|l|}{ Octopodiformes } \\
\hline \multicolumn{7}{|l|}{ Argonautidae } \\
\hline Argonauta spp. & 26.09 & 17.60 & 67.46 & 14.52 & 55.65 & 16.06 \\
\hline \multicolumn{7}{|l|}{ Bolitaenidae } \\
\hline Japetella diaphana & 7.83 & 3.61 & 46.18 & 3.15 & 40.21 & 3.38 \\
\hline Japetella heathi & 1.74 & 0.34 & 19.64 & $<0.01$ & $<0.01$ & 0.17 \\
\hline Enteroctopodidae & & & & & & \\
\hline Muusoctopus sp. & 0.87 & 0.14 & 16.67 & 0.01 & 0.73 & 0.08 \\
\hline Octopodidae & & & & & & \\
\hline Eledone spp. & 0.87 & 0.05 & 5.71 & $<0.01$ & $<0.01$ & 0.02 \\
\hline Tremoctopodidae & & & & & & \\
\hline Tremoctopus violaceus & 1.74 & 0.10 & 5.72 & 0.01 & 0.77 & 0.06 \\
\hline Vitreledonellidae & & & & & & \\
\hline Vitreledonella richardi & 1.74 & 0.07 & 4.26 & $<0.01$ & 0.00756 & 0.04 \\
\hline Vampyromorphida & & & & & & \\
\hline Vampyroteuthidae & & & & & & \\
\hline Vampyroteuthis infernalis & 6.96 & 2.42 & 34.82 & 2.96 & 42.55 & 2.69 \\
\hline Unidentified cephalopods & 33.04 & 29.57 & 89.47 & 33.04 & 99.98 & 31.30 \\
\hline
\end{tabular}




\begin{tabular}{|c|c|c|c|c|c|c|}
\hline Prey species & $\% \mathrm{FO}$ & $\% \mathrm{~N}$ & $\% \mathrm{PN}$ & $\% \mathrm{~W}$ & $\% \mathrm{PW}$ & $\%$ PSIRI \\
\hline \multicolumn{7}{|l|}{ TELEOSTEI } \\
\hline \multicolumn{7}{|l|}{ Clupeiformes } \\
\hline \multicolumn{7}{|l|}{ Engraulidae } \\
\hline Engraulis ringens & 2.61 & 1.12 & 42.91 & 1.52 & 58.43 & 1.32 \\
\hline \multicolumn{7}{|l|}{ Gadiformes } \\
\hline \multicolumn{7}{|l|}{ Macrouridae } \\
\hline Coryphaenoides sp. & 0.87 & 0.02 & 2.86 & $<0.01$ & $<0.01$ & 0.01 \\
\hline \multicolumn{7}{|l|}{ Merlucciidae } \\
\hline Merluccius gayi peruanus & 0.87 & 0.05 & 6.25 & 0.56 & 63.94 & 0.31 \\
\hline \multicolumn{7}{|l|}{ Myctophiformes } \\
\hline \multicolumn{7}{|l|}{ Myctophidae } \\
\hline Myctophum aurolaternatum & 0.87 & 0.09 & 10.00 & $<0.01$ & 0.03 & 0.04 \\
\hline \multicolumn{7}{|l|}{ Perciformes } \\
\hline \multicolumn{7}{|l|}{ Coryphaenidae } \\
\hline Coryphaena hippurus & 1.74 & 0.43 & 25.00 & 1.65 & 94.84 & 1.04 \\
\hline \multicolumn{7}{|l|}{ Scombridae } \\
\hline Auxis thazard & 0.87 & 0.08 & 9.09 & 0.02 & 2.87 & 0.05 \\
\hline \multicolumn{7}{|l|}{ Sphyraenidae } \\
\hline Sphyraena idiastes & 0.87 & 0.11 & 12.50 & $<0.01$ & $<0.01$ & 0.05 \\
\hline Unidentified fishes & 22.61 & 8.71 & 38.53 & 3.51 & 15.51 & 6.11 \\
\hline \multicolumn{7}{|l|}{ MAMMALIA } \\
\hline \multicolumn{7}{|l|}{ Cetacea } \\
\hline Delphinidae & 1.74 & 0.23 & 12.96 & 0.91 & 52.29 & 0.57 \\
\hline Delphinus capensis & 0.87 & 0.29 & 33.33 & 0.25 & 28.61 & 0.27 \\
\hline \multicolumn{7}{|l|}{ CRUSTACEA } \\
\hline \multicolumn{7}{|l|}{ Decapoda } \\
\hline \multicolumn{7}{|l|}{ Galatheidae } \\
\hline Pleuroncodes monodon & 0.87 & 0.84 & 97.14 & 0.81 & 92.64 & 0.83 \\
\hline Unidentified crustaceans & 5.22 & 0.70 & 13.42 & $<0.01$ & 0.06 & 0.35 \\
\hline \multicolumn{7}{|l|}{ AVES } \\
\hline Unidentified bird & 0.87 & 0.11 & 12.50 & $<0.01$ & 0.31 & 0.06 \\
\hline \multicolumn{7}{|l|}{ EGGS } \\
\hline Exocoetidae eggs & 7.83 & 2.17 & 27.76 & 2.25 & 28.75 & 2.21 \\
\hline
\end{tabular}

1993). The $R$-statistic values from ANOSIM describe the extent of similarity, where $R=0$ refers to an identical diet and $R= \pm 1$ is indicative of the most divergent diet (Clarke, 1993). Similarity percentages (SIMPER) were used, as well, to determine the prey categories, by family, that typified particular groups, or contributed most to the similarities between groups, or both (Clarke, 1993). Finally, the semiparametric permutation multivariate analyses of variance (PERMANOVA) test on the Bray-Curtis index of dissimilarity (based on numeric abundance) was used to test whether an interaction was present between factors that were significant according to the pairwise tests (ANOSIM).

Statistical analyses were conducted with the software RStudio, vers. 1.1.453 (RStudio, 2018) with R, vers. 3.5.0 ( $\mathrm{R}$ Core Team, 2018). Descriptive statistics are presented with mean standard deviations (SDs).

\section{Results}

A total of 143 stomachs of blue sharks were obtained from the ports of Mancora $(n=43)$ and Salaverry $(n=100)$.
Of these, 115 (80.4\%) had food remains and $28(19.6 \%)$ were empty. Of those individuals with food remains, 47 were female (range: 165-293 cm TL; mean: $214 \mathrm{~cm}$ TL [SD 35] and 68 were male (range: 110-288 cm TL; mean: $220 \mathrm{~cm}$ TL [SD 41]). A cumulative prey curve was constructed on the basis of 74 stomach contents because 41 stomachs containing only 'unidentified remains' were excluded. The curve slope was 0.9 , indicating that the sampling size was sufficient to describe the diet of blue sharks. However, according to the Bizzarro's et al. (2007) method, the curve did not reach an asymptote $(P<0.05)$, and therefore suggests that the results presented here do not fully describe the blue shark diet.

Prey comprised 42 taxonomic levels (Table 1). Cephalopods represented the main prey group (87.4\% PSIRI), followed by fishes (8.5\% PSIRI), flying fish eggs $(2.1 \%$ PSIRI), crustaceans (1.1\% PSIRI), and marine mammal and bird remains $(0.8 \%$ and $0.1 \%$ PSIRI, respectively). The prey item 'unidentified cephalopods' (represented by flesh, gladii, and eye lenses) was the most important (31.3\% PSIRI) in the overall analysis, followed by Argonauta spp. (16.1\% PSIRI) and A. lesueurii $(6.2 \%$ PSIRI) (Table 1; Fig. 2). 


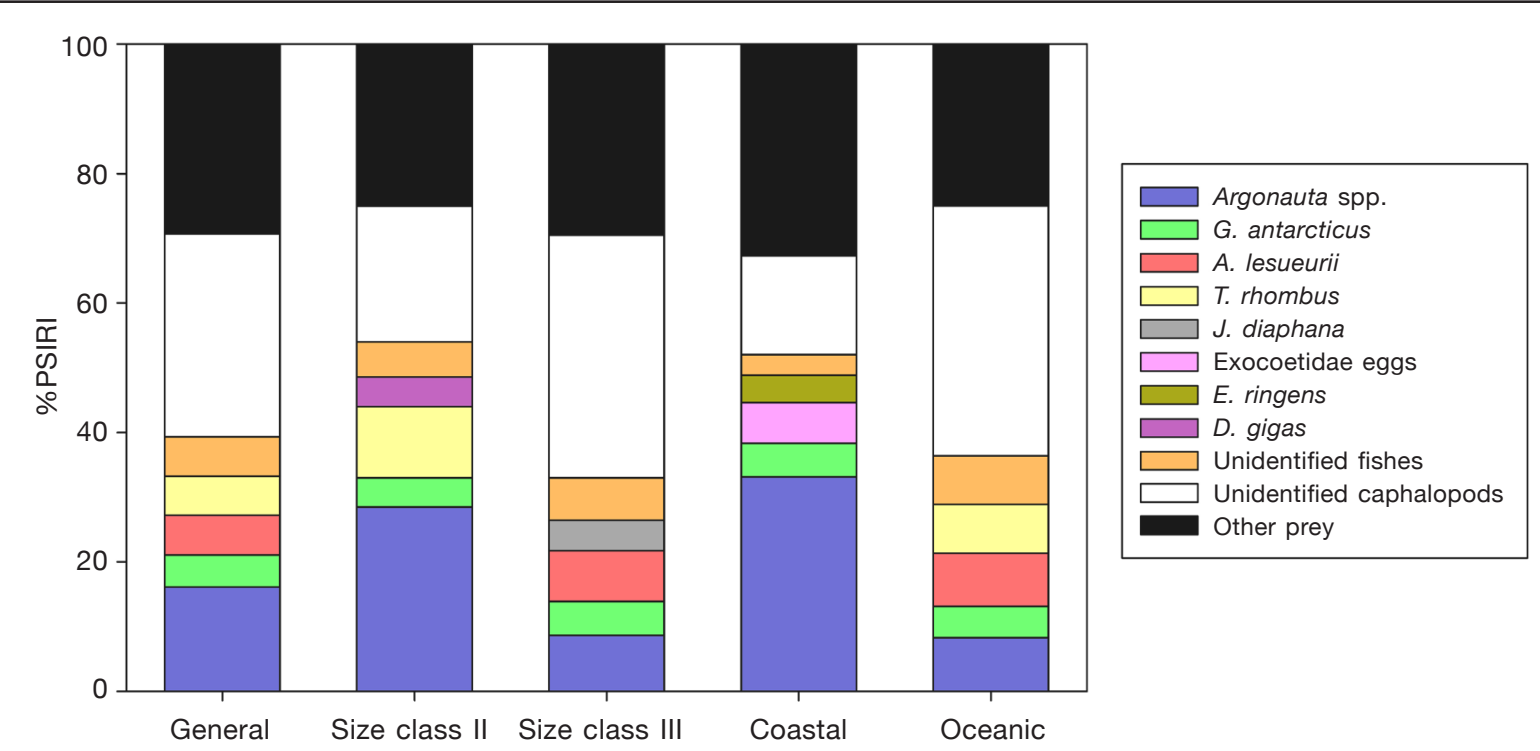

Figure 2

Prey-specific index of relative importance (\%PSIRI) of the overall diet of blue sharks (Prionace glauca) sampled in northern Peru between February and December 2015, by size class and longitude of fishing ground. Size class II represents fish $150.0-229.9 \mathrm{~cm}$ in total length (TL) and size class III represents fish $230.0-309.9 \mathrm{~cm}$ TL; size class I had only 2 samples and was excluded from most analyses. Two regions were used for analyses with longitudes: coastal and oceanic, delineated by the Peru-Chile Trench (which has an average distance from shore of $130 \mathrm{~km}$ or 70 nautical miles). Taxa include Argonauta spp., Gonatus antarcticus, Ancistrocheirus lesueurii, the diamond squid (Thysanoteuthis rhombus), Japetella diaphana, flying fish (Exocoetidae) eggs, the Peruvian anchoveta (Engraulis ringens), and the jumbo squid (Dosidicus gigas).

\section{Table 2}

Levin's standardized index $\left(B_{\mathrm{i}}\right.$ ), analysis of similarity (ANOSIM), and trophic position (TP) of blue sharks (Prionace glauca) from which stomach contents were collected between February and December 2015 off northern Peru, by size class and longitude of fishing ground. Size class II represents fish 150.0-229.9 cm in total length (TL) and size class III represents fish 230.0-309.9 cm TL; size class I had only 2 samples and was excluded from most analyses. Two regions, coastal and oceanic, were used for the analyses with longitudes of fishing grounds: these regions are separated by the Peru-Chile Trench (which has an average distance from shore of $130 \mathrm{~km}$ or 70 nautical miles). General=overall analysis.

\begin{tabular}{lcccc}
\hline Factor & Subfactor & ANOSIM & $B_{\mathrm{i}}$ & TP \\
\hline General & - & - & 0.26 & 4.4 \\
Size class & II & II vs III $(R=0.05 ;$ & 0.19 & 4.4 \\
& III & $\left.P<0.05^{*}\right)$ & 0.42 & 4.4 \\
Fishing ground longitude & Coastal & Coastal vs. oceanic & 0.18 & 4.4 \\
& Oceanic & $\left(R=0.10 ; P<0.01^{*}\right)$ & 0.40 & 4.4 \\
\end{tabular}

The niche breadth of the blue shark was considered narrow according to Levin's standardized index (Table 2 ), indicating a higher degree of specialization. The graphical analysis suggests a similar feeding pattern, with a clear dominance of the Argonautidae family (Fig. 3). Additionally, the trophic position of the blue shark was calculated as 4.4 , indicating that the blue shark is a high trophic-level consumer within the food web off northern Peru.

Size class groups were evaluated at $20-$ and $30-\mathrm{cm}-$ TL intervals and showed no clear organization of size classes. Nevertheless, cluster analysis with a $40-\mathrm{cm}-$ TL interval showed positive results, with 3 size classes identified at $50 \%$ of Bray-Curtis dissimilarity (Fig. 4). 


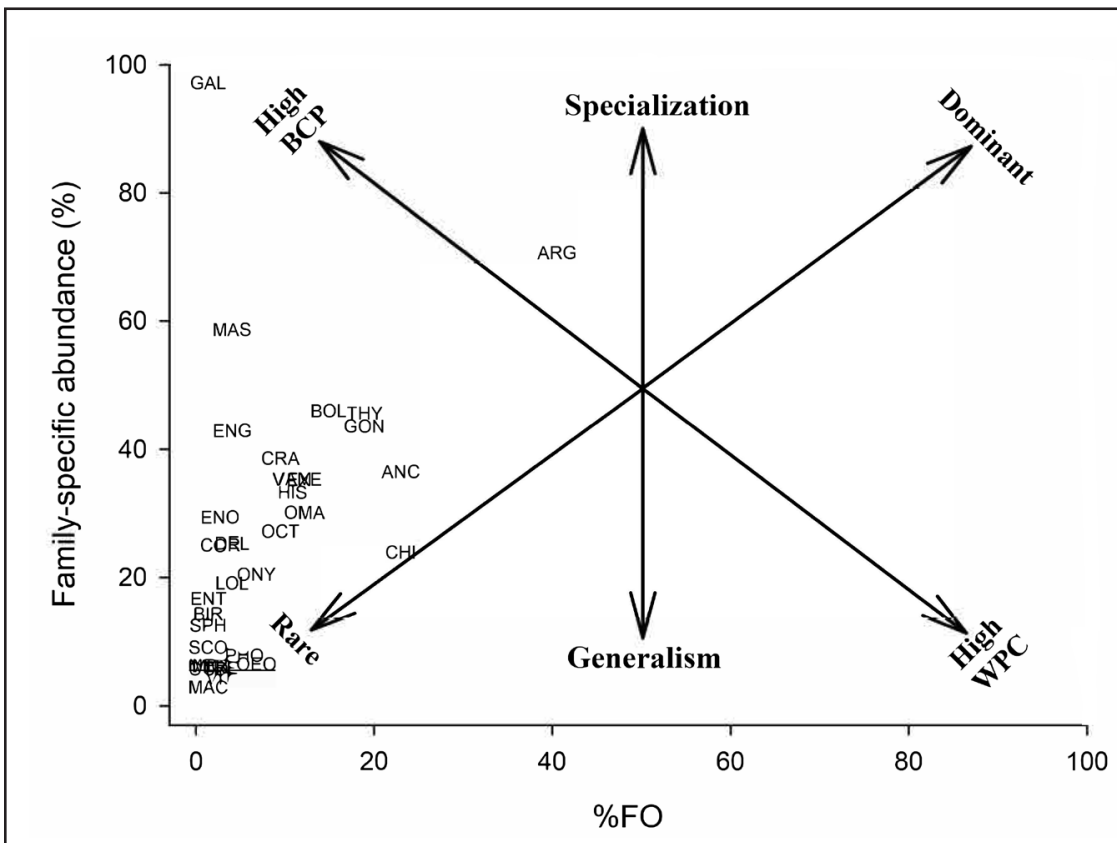

Figure 3

Prey-specific abundance at a family level plotted against the frequency of occurrence $(\% \mathrm{FO})$ for families of prey species found in analysis of stomach contents of blue sharks (Prionace glauca) sampled in northern Peru between February and December 2015. The explanatory axes for foraging patterns are those modified by Amundsen et al. (1996). The 2 diagonal axes represent the importance of prey (dominant versus rare) and the contribution to niche width (high between-phenotype contribution [BPC] versus high within-phenotype contribution [WPC]). The vertical axis defines the predator feeding strategy. The families include Ancistrocheiridae (ANC), Argonautidae (ARG), Bolitaenidae (BOL), Chiroteuthidae (CHI), Coryphaenidae (COR), Cranchiidae (CRA), Delphinidae (DEL), Engraulidae (ENG), Enoploteuthidae (ENO), Enteroctopodidae (ENT), Galatheidae (GAL), Gonatidae (GON), Histioteuthidae (HIS), Loliginidae (LOL), Macrouridae (MAC), Mastigoteuthidae (MAS), Merlucciidae (MER), Myctophidae (MYC), Octopodidae (OCD), Octopoteuthidae (OCT), Oeogopsidae (OEO), Ommastrephidae (OMA), Onychoteuthidae (ONY), Pholidoteuthidae (PHO), Scombridae (SCO), Sphyraenidae (SPH), Thysanoteuthidae (THY), Tremoctopodidae (TRE), Vampyroteuthidae (VAM), and Vitreledonellidae (VIT). Other stomach contents include one bird (BIR) and flying fish (Exocoetidae) eggs (EXO).

However, because size class I (110.0-149.9 cm TL) was represented by only 2 samples, only size class II (150.0$229.9 \mathrm{~cm} \mathrm{TL}, n=32)$ and size class III $(230.0-309.9 \mathrm{~cm}$ TL, $n=40$ ) were considered for subsequent analyses.

From all the factors assessed (sex, season, size class, and fishing ground [by latitude and longitude]), ANOSIM showed a significant difference in the diet by size class and fishing ground longitude. These differences were small (Table 2), but indicated that an overlap exists between the composition of dietary factors (Clarke, 1993). A small difference in diet composition existed between size class II and III (Table 2). The nonmetric MDS plot showed that this small difference is explained by an overlap of diets (Fig. 5A). According to SIMPER analysis, in order of importance, the prey families that most contributed to the diet of size class II were Argo- nautidae and Thysanoteuthidae, whereas in size class III they were Argonautidae and Ancistrocheiridae. The \%PSIRI for size classes showed a similar trend (Fig. 2). Argonauta spp. represented the main prey taxon for both size classes, although a considerable decrease in this taxon was observed from size class II (28.5\%) to size class III $(8.6 \%)$. Furthermore, larger size individuals (size class III) exhibited a tendency to forage on other prey species such as A. lesueurii (7.8\%) and Japetella diaphana (4.7\%), in addition to an increase in the importance of 'unidentified cephalopods' in the diet. Niche breadth analysis revealed that both groups had high degrees of specialization, even though higher values were estimated for size class III (Table 2). Blue sharks of both groups were considered top predators (Table 2). 


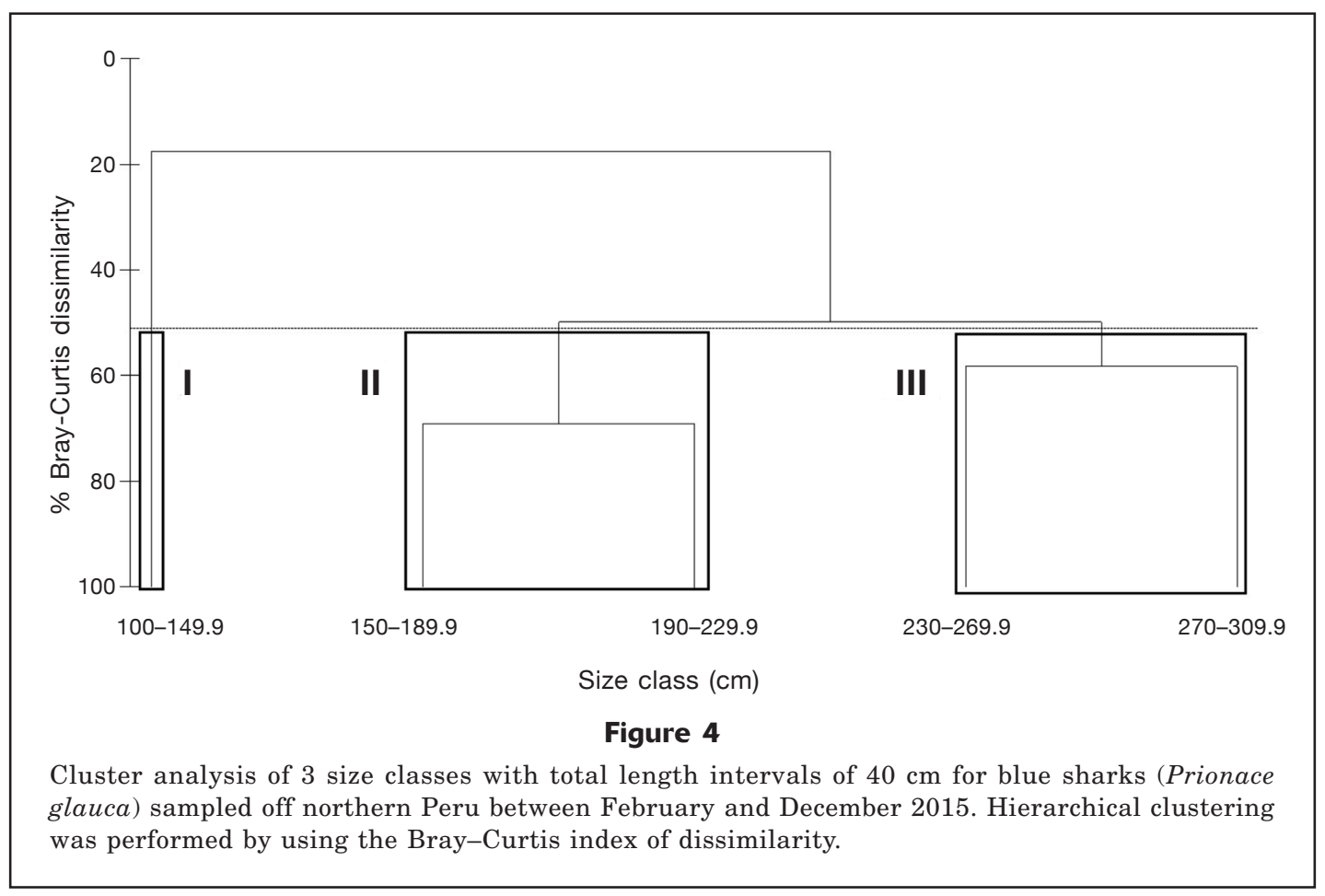

The nonmetric MDS ordination for fishing ground longitude showed that the diets of both groups overlapped (Fig. 5B). This overlap explains the small difference calculated with ANOSIM (Table 2). SIMPER analysis revealed that, in order of importance, Argonautidae and Chiroteuthidae contributed more to the diet of blue sharks in the coastal zone, whereas Ancistrocheiridae and Argonautidae contributed more to the diet of individuals in the oceanic zone. Trophic positions in both longitudinal zones were similar and Levin's standardized index revealed that blue sharks had a higher degree of diet specialization in both zones, although higher values were estimated for the oceanic zone (Table 2). Values of \%PSIRI for longitudinal zones (Fig. 2) showed that the coastal zone diet $(n=36)$ was predominated by Argonauta spp. (33.2\%), flying fish eggs $(6.3 \%)$, Gonatus antarcticus (5.2\%), and Peruvian anchoveta $(4.2 \%)$. In contrast, the oceanic zone $(n=79$ stomachs) had a much lower percentage of Argonauta spp. (8.3\%), in addition to A. lesueurii (8.2\%) and diamond squid (Thysanoteuthis rhombus, $7.6 \%$ ). Furthermore, 'unidentified cephalopods' varied greatly between coastal $(15.3 \%)$ and oceanic $(38.6 \%)$ zones.

Finally, the PERMANOVA test (pseudo- $F=0.7961$, $P>0.05)$ indicated no interaction between the 2 size classes and coastal and oceanic fishing grounds.

\section{Discussion}

The present study provides important new information on the diet of blue sharks in Peruvian waters. In this study, cephalopods represented $87.4 \%$ PSIRI of overall diet, and $66.7 \%$ of total prey species identified. These results validate, for Peruvian waters, the preference of blue sharks to prey on squid in the eastern Pacific Ocean (Markaida and Sosa-Nishizaki, 2010; Loor-Andrade et al., 2017). Furthermore, our results showed that small quantities of fish were consumed $(8.5 \%$ PSIRI). It is important, however, to note that fish consumption is likely underestimated because both fish flesh and otoliths degrade faster than cephalopod flesh and beaks (Tricas, 1979; Hernández-García, 1995).

Blue sharks have been described as meso- and bathypelagic predators (Clarke et al., 1996). They are known to swim at depths near the thermocline at night, whereas during daylight hours, they prefer to dive and complete long incursions to great depths (Carey and Scharold, 1990). Campana et al. (2011) stated that this behavior was highly related to the diel vertical migrations of their preferred prey (i.e., cephalopods), which feed in the epipelagic zone at night and move to greater depths during daylight hours. Our identification of mesopelagic (e.g., Ancistrocheiridae, Histioteuthidae, Gonatidae cephalopods) and bathypelagic (i.e., Vampyroteuthis infernalis) prey in significant quantities, suggests that, at least for the area studied, they also completed vertical migrations to feed on preferred or available prey, or both (Roper and Young, 1975).

Argonauta spp. off the coast of northern Peru have been studied little and have been described only as fauna associated with prospections associated with the Peruvian anchoveta fishery in the northern Humboldt ecosystem (between $4-16^{\circ} \mathrm{S}$ and $0-148 \mathrm{~km}$ from shore) 


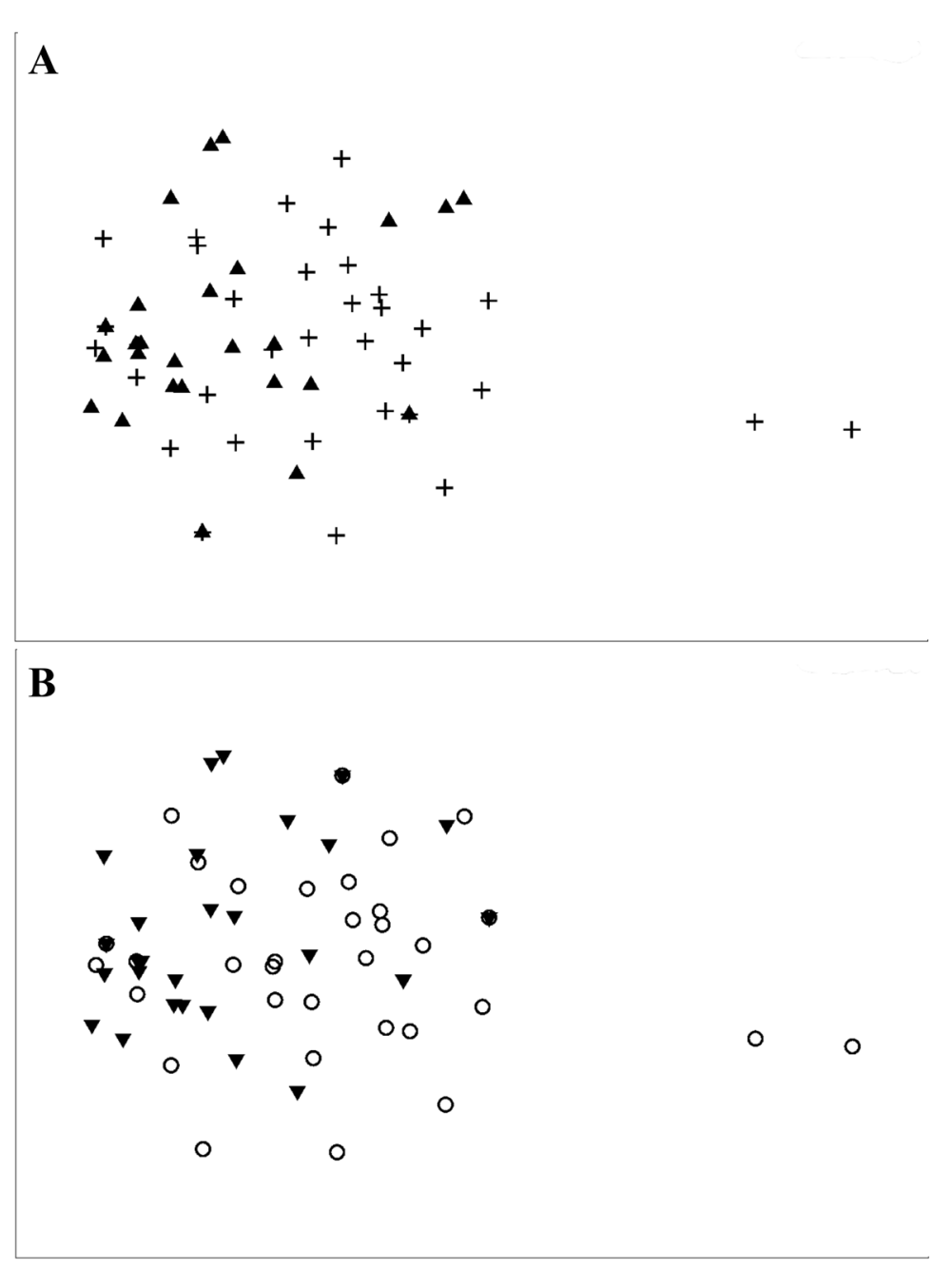

Figure 5

Nonmetric multidimensional scaling plots comparing distributions of (A) size classes II ( $\mathbf{A})$ and III (+) and $(\mathbf{B})$ oceanic $(\boldsymbol{\nabla})$ and coastal (O) fishing grounds for blue sharks (Prionace glauca) collected off northern Peru between February and December 2015. Size class II represents fish 150.0-229.9 cm in total length (TL), and size class III represents fish 230.0-309.9 cm TL. The coastal and oceanic fishing grounds were categorized by using the Peru-Chile Trench (with an average distance from shore of $130 \mathrm{~km}$ or 70 nautical miles) as the boundary. The stress level of this plot is 0.06 . vian coast, while Sajinez et al. (2016) mentioned that Argonauta spp. abundance is highly related to SST, with increased abundance during positive anomalies. During the sampling year, an SST positive anomaly of $1.7^{\circ} \mathrm{C}$ (SD 1.2) $\left(\mathrm{DHN}^{5}\right)$ was reported for the Niño $1+2$ region (in the eastern equatorial Pacific Ocean between $0-10^{\circ} \mathrm{S}$ and $90-80^{\circ} \mathrm{W}$ ). Therefore, the elevated consumption of Argonauta spp. that we observed (16.1\% PSIRI) may have been a response to higher abundances of this species during the SST positive anomaly if we consider the opportunistic foraging behavior of the blue shark upon abundant available prey (Stevens, 1973). The elevated consumption of Argonauta spp. is what most makes the blue shark a consumer with a high degree of specialization. However, further investigations are needed to further confirm this feeding pattern and to evaluate how this degree of specialization varies during La Niña periods.

The consumption of flying fish eggs (in patches) recorded in this study may suggest, as Nakano and Seki (2003) proposed, the ingestion of prey (or objects) whose silhouettes are detected against light from the sea surface. However, the maximum number of individuals of certain small-size species (e.g., Argonauta spp.=102, P. monodon=34, Doryteuthis (Amerigo) gahi=25, Peruvian anchoveta $=24$, Grimalditeuthis bonplandi=14) reported in different samples may also reflect a habit of foraging upon shoals of small-size species (Tricas, 1979). Furthermore, Tricas (1979) indicated that blue sharks benefit from schools of spawning squid, such as those of the opalescent inshore squid (Loligo opalescens). Therefore, Argonauta spp. could be prey of blue sharks within spawning areas of Argonauta spp. off northern Peru, as well, especially considering that abundant fertilized and nonfertilized Argonautidae eggs were found in 21 stomachs.
(IMARPE ${ }^{4}$ ) and as a component of the diet of dolphinfish (Coryphaena hippurus) (Solano et al., 2015). However, recent investigations have begun to assess basic aspects of its ecology. Orosco-Montenegro (2016) reported that the abundance of larvae of Argonauta spp. is higher during the summer (318 individuals $/ \mathrm{m}^{2}$ ) than during the fall (9 individuals $/ \mathrm{m}^{2}$ ) along the Peru-

${ }^{4}$ IMARPE (Instituto del Mar del Peru). 2015. Crucero 1502-04 de "Evaluación hidroacústica de los recursos pelágicos.” Inst. Mar Peru, Inf. Ejec., 42 p. [Available from website]

\section{Scavenger behavior}

Blue sharks are considered active scavengers in the open ocean (Garibaldi and Orsi Relini, 2000). However, this behavior has only been discussed because of the discovery of cephalopod and marine mammal parts in stomachs of blue sharks (Markaida and Sosa-Nishiza-

${ }^{5}$ DHN (Dirección de Hidrografía y Navegación). 2015. Anomalías de la temperatura superficial del mar en el Pacífico ecuatorial. Bol. Oceanogr., December 2015, 9 p. [Available from website] 
ki, 2010; Klarian et al., 2018). In this study we sought to reinforce these studies with a new approach, i.e., with the consideration of the cosmopolitan duck barnacle (Lepas anatifera) as a bioindicator of scavenging behavior.

The duck barnacle is a cosmopolitan species that as an adult is commonly found attached to floating objects (Hinojosa et al., 2006). Its cyprid larval stage denotes the shift from a free-swimming organism to a sessile organism. During this stage, cyprid larvae are forced to find a favorable place to settle and metamorphose into juvenile duck barnacles (Høeg et al., 2012). The most common substrate used by cyprid larvae are animals and floating objects, such as boats, buoys (Sneli, 1983), wood (Minchin, 1996), macroalgae (Hinojosa et al., 2006), turtles (Casale et al., 2012), and even fish (Zevina and Memmi, 1981). However, we believe that other substrates could be used by duck barnacle in the open ocean, for example, moribund spent females of many deep-water cephalopods that float passively to the ocean surface and die (Nesis, 1996). Indeed, Markaida and Sosa-Nishizaki (2010) stated that blue sharks may easily scavenge on these dead buoyant cephalopods. In our study, two stages of duck barnacle-cyprid larvae (60.1\%, range: $1-200$ individuals) and juveniles $(9.1 \%$, range: 1-3) (Suppl.Fig.)-were found in stomachs containing only the prey 'unidentified cephalopods' $(n=40)$. We believe that at least some of the ingestion of cephalopods was the result of scavenging behavior. The possible scavenging behavior of blue sharks is also reinforced by findings of duck barnacle cyprid larvae in samples containing skin, blubber, muscle tissue, and dorsal fin of marine mammals, and in the keeled sternum of an 'unidentified bird' (Klarian et al., 2018).

\section{Dietary variability by ontogenetic factors}

Ontogenetic shifts have been described in the diets of several shark species-shifts that are mainly due to energetics, metabolism, or changes in foraging ability (Grubbs, 2010). In the case of blue sharks, some studies have tried to prove these ontogenetic shifts, however, with no success (Markaida and Sosa-Nishizaki, 2010; Hernández-Aguilar et al., 2016).

Length at first maturity of blue sharks in the southeastern Pacific Ocean has been reported to be around $200 \mathrm{~cm}$ TL (Bustamante and Bennett, 2013). Therefore, size class II in our study was considered to comprise both juvenile and small adults, with a large predominance $(82 \%)$ of juveniles. Juvenile blue sharks $(\mathrm{TL}<200 \mathrm{~cm})$ have a narrow coastal distribution before they take part in larger-scale migrations (Vandeperre et al., 2014). Litvinov (2006) supported the idea that this spatial isolation of juvenile blue sharks is caused by limitations on prey consumption at the earliest age, specifically during the period of development of teeth cusps. In addition, Vandeperre et al. (2014) stated that coastal areas may provide juvenile blue sharks (fork length $<185 \mathrm{~cm}$ ) with optimal growth conditions because of the availability of food resources that are associated with the diversity of topographic features (seamounts and islands), and localized oceanographic processes. In our study, the large abundance of smallsize octopods, such as Argonauta spp., in the diet of individuals from size class II and in the diet of those captured in the coastal zone (Fig. 2), reaffirms the hypothesis that small-size blue sharks occur in coastal areas and feed upon available prey items.

Vertical and horizontal movements of blue sharks expand progressively as body size increases, and according to migratory patterns throughout their life history (Nakano and Stevens, 2008). The smaller quantities of Argonauta spp. and the appearance of the oceanic squid $A$. lesueurii in the diet of individuals from size class III (100\% adults) and from oceanic areas (Fig. 2) may indicate longitudinal movements of larger blue sharks from coastal to oceanic areas (Vögler et al., 2012). Moreover, the presence of cephalopods from deeper depths, such as J. diaphana or $V$. infernalis, in the diet of size class III may indicate progressive dives to greater depths by larger individuals (Roper and Young, 1975).

In this article we have provided important new information about the food habits of blue sharks off northern Peru. Blue sharks feed on small-size (Argonauta spp.) and larger size (A. lesueurii) prey species, which indicate a surface and mesobathypelagic foraging behavior. In addition, we identified prey items with commercial importance, such as jumbo squid, $D$. gahi, Peruvian anchoveta, and flying fish eggs in the diet of blue sharks, which highlight the importance of the results from this study for Peruvian ecosystem management.

\section{Acknowledgments}

We thank F. Galván-Magaña and J. Xavier for assisting with cephalopod beak identification, as well as J. Ramón-Ortega for his advice with statistics. The authors also thank all onboard observers who participated in this study, as well as E. Alfaro, J. Coasaca, S. Pingo, A. Jimenez, and ProDelphinus staff. This study was funded by the Fondo para la Innovación, la Ciencia y la Tecnología (contract no. 369-PNICP-PIBA-2014), the Darwin Initiative, and the U.S. State Department through the U.S. Embassy in Lima.

\section{Literature cited}

Adams, G. D., D. Flores, O. Galindo Flores, K. Aarestrup, and J. C. Svendsen.

2016. Spatial ecology of blue shark and shortfin mako in southern Peru: local abundance, habitat preferences and implications for conservation. Endang. Species Res. 31:1932. Article

Alfaro-Shigueto, J., J. C. Mangel, M. Pajuelo, P. H. Dutton, J. A. Seminoff, and B. J. Godley.

2010. Where small can have a large impact: structure and 
characterization of small-scale fisheries in Peru. Fish. Res. 106:8-17. Article

Amundsen, P.-A., H.-M. Gabler, and F. J. Staldvik.

1996. A new approach to graphical analysis of feeding strategy from stomach contents data-modification of the Costello (1990) method. J. Fish Biol. 48:607-614. Article

Bigelow, H. B., and W. C. Schroeder.

1948. Sharks. In Fishes of the western North Atlantic, part 1: lancelets, cyclostomes, sharks (A. E. Parr and Y. H. Olsen, eds.), p. 59-546. Sears Found. Mar. Res. Mem. 1, Yale Univ., New Haven, CT.

Bizzarro, J. J., H. J. Robinson, C. S. Rinewalt, and D. A. Ebert.

2007. Comparative feeding ecology of four sympatric skate species off central California, USA. Environ. Biol. Fish. 80:197-220. Article

Brown, S. C., J. J. Bizzarro, G. M. Cailliet, and D. A. Ebert.

2012. Breaking with tradition: redefining measures for diet description with a case study of the Aleutian skate Bathyraja aleutica (Gilbert 1896). Environ. Biol. Fish. 95:3-20. Article

Bustamante, C., and M. B. Bennett.

2013. Insights into the reproductive biology and fisheries of two commercially exploited species, shortfin mako (Isurus oxyrinchus) and blue shark (Prionace glauca), in the south-east Pacific Ocean. Fish. Res. 143:174-183. Article

Campana, S. E., A. Dorey, M. Fowler, W. Joyce, Z. Wang, D.

Wright, and I. Yashayaev.

2011. Migration pathways, behavioural thermoregulation and overwintering grounds of blue sharks in the northwest Atlantic. PLoS ONE 6(2):e16854. Article

Casale, P., M. D’Addario, D. Freggi, and R. Argano.

2012. Barnacles (Cirripedia, Thoracica) and associated epibionts from sea turtles in the central Mediterranean. Crustaceana 85(4-5):533-549. Article

Chirichigno, N., and J. Velez.

1998. Clave para identificar los peces marinos del Perú, $2^{\text {nd }}$ ed., 496 p. Publ. Espec., Inst. Mar Peru, Callao, Peru.

Chirichigno, N., and R. M. Cornejo.

2001. Catálogo comentado de los peces marinos del Perú, 314 p. Publ. Espec., Inst. Mar Peru, Callao, Peru.

Christensen, V., and D. Pauly.

1992. ECOPATH II-a software for balancing steady-state ecosystem models and calculating network characteristics. Ecol. Model. 61:169-185. Article

Carey, F. G., and J. V. Scharold.

1990. Movements of blue sharks (Prionace glauca) in depth and course. Mar. Biol. 106:329-342. Article

Clarke, K. R.

1993. Non-parametric multivariate analysis of changes in community structure. Aust. J. Ecol. 18:117-143. Article

Clarke, M. R. (ed.).

1986. A handbook for the identification of cephalopod beaks, 273 p. Clarendon Press. Oxford, UK.

Clarke, M. R., D. C. Clarke, H. R. Martins, and H. M. Da Silva.

1996. The diet of the blue shark (Prionace glauca L.) in Azorean waters. Arquipélago Life Mar. Sci. 14A:41-56.

Clarke, S. C., M. K. McAllister, E. J. Milner-Gulland, G. P. Kirkwood, C. G. J. Michielsens, D. J. Agnew, E. K. Pikitch, H. Nakano, and M. S. Shivji.

2006. Global estimates of shark catches using trade re- cords from commercial markets. Ecol. Lett. 9:1115-1126. Article

Clothier, C. R.

1950. A key to some southern California fishes based on vertebral characters. Calif. Dep. Fish Game Fish Bull. $79,83 \mathrm{p}$.

Colwell, R. K.

2013. EstimateS: statistical estimation of species richness and shared species from samples. Version 9.1.0 user's guide. [Available from website.]

Cornejo, R., X. Vélez-Zuazo, A. González-Pestana, C. Kouri, and G. Mucientes.

2015. An updated checklist of Chondrichthyes from the southeast Pacific off Peru. Check List 11(6):1809. Article

Cortés, E.

1997. A critical review of methods of studying fish feeding based on analysis of stomach contents: application to elasmobranch fishes. Can. J. Fish. Aquat. Sci 54:726-738. Article

1999. Standardized diet compositions and trophic levels of sharks. ICES J. Mar. Sci. 56:707-717. Article

Doherty, P. D., J. Alfaro-Shigueto, D. J. Hodgson, J. C. Mangel, M. J. Witt, and B. J. Godley.

2014. Big catch, little sharks: insight into Peruvian small-scale longline fisheries. Ecol. Evol. 4:2375-2383. Article

Ebert, D. A., and J. J. Bizzarro.

2007. Standardized diet compositions and trophic levels of skates (Chondrichthyes: Rajiformes: Rajoidei). Environ. Biol. Fish. 80:221-237. Article

Elliot, W., F. Paredes, and M. Bustamante.

1995. Biología y pesquería de tiburones de las Islas Lobos, Perú. Inf. Prog. Inst. Mar Peru 16:5-22.

1996. II prospección biológico-pesquera de "tiburones" al oeste de las Islas Lobos, ynero 1996. Inf. Prog. Inst. Mar Peru 41:3-17.

Espinoza, P.

2014. Trophic dynamics in the northern Humboldt Current system: insights from stable isotopes and stomach content analyses. Ph.D. diss., 131 p. Univ. Bretagne Occidentale, Brest, France.

Fernández, F.

1987. Edad y crecimiento de la merluza Peruana (Merluccius gayi peruanus). Bol. Inst. Mar Peru 11:191-220.

Flores, R., M. Espino, G. Luque, and J. Quispe.

2013. Patrones de variabilidad ambiental en el mar peruano. Rev. Peru Biol. 20:21-28. Article

Galván-Magaña, F., H. J. Nienhuis, and A. P. Klimley.

1989. Seasonal abundance and feeding habits of sharks of the lower Gulf of California, Mexico. Calif. Fish Game 75(2):74-84.

García-Godos, I.

2001. Patrones morfológicos del otolito Sagitta de algunos peces óseos del mar Peruano. Bol. Inst. Mar Perú 20:1-83.

Garibaldi, F., and L. Orsi Relini.

2000. Summer abundance size and feeding habits of the blue shark, Prionace glauca, in the pelagic sanctuary of the Ligurian Sea. Biol. Mar. Mediterr. 7:324-333. [In Italian with English abstract.]

Goicochea, C., and S. Arrieta.

2008. Variaciones en crecimiento de la anchoveta peruana expresadas en los radios de otolitos. Inf. Inst. Mar. Peru 35:241-244. 
Grubbs, R. D

2010. Ontogenetic shifts in movements and habitat use. In Sharks and their relatives II: biodiversity, adaptive physiology, and conservation (J. C. Carrier, J. A. Musick, and M. R. Heithaus, eds.), p. 319-350. CRC Press, Boca Raton, FL.

Harvey, J. T.

1989. Food habits, seasonal abundance, size, and sex of the blue shark, Prionace glauca, in Monterey Bay, California. Calif. Fish Game 75(1):33-44.

Hernández-Aguilar, S. B., O. Escobar-Sánchez, F. GalvánMagaña, and L. A. Abitia-Cárdenas.

2016. Trophic ecology of the blue shark (Prionace glauca) based on stable isotopes $\left(\delta^{13} \mathrm{C}\right.$ and $\left.\delta^{15} \mathrm{~N}\right)$ and stomach content. J. Mar. Biol. Assoc. U.K. 96:1403-1410. Article

Hernández-García, V.

1995. The diet of the swordfish Xiphias gladius Linnaeus, 1758 , in the central east Atlantic, with emphasis on the role of cephalopods. Fish. Bull. 93:403-411.

Hinojosa, I., S. Boltaña, D. Lancellotti, E. Macaya, P. Ugalde, N. Valdivia, N. Vásquez, W. A. Newman, and M. Thiel.

2006. Geographic distribution and description of four pelagic barnacles along the south east Pacific coast of Chile-a zoogeographical approximation. Rev. Chil. Hist. Nat. 79:13-27.

Høeg, J. T., D. Maruzzo, K. Okano, H. Glenner, and B. K. K. Chan.

2012. Metamorphosis in balanomorphan, pedunculated, and parasitic Barnacles: a video-based analysis. Integr. Comp. Biol. 52:337-347.

Hoyos, L., J. Tarazona, G. Marquina, D. Velarde, and S. Valle. 1991. Ecologia trofica de Prionace glauca "tintorera" de la costa central del Peru. In I Reunión Anual del ICBAR libro de resúmenes; Lima, Peru, 4-6 November, p. 75. Instituto de Investigación de Ciencias Biológicas "Antonio Raimondi" (ICBAR), Universidad Nacional Mayor de San Marcos, Lima, Peru.

Jefferson, T., M. Webber, and R. Pitman

2015. Marine mammals of the world: a comprehensive guide to their identification, $2^{\text {nd }}$ ed., 616 p. Academic Press, Cambridge, MA.

Jiménez-Valverde, A., and J. Hortal.

2003. Las curvas de acumulación de especies y la necesidad de evaluar la calidad de los inventarios biológicos. Rev. Ibér. Aracnología 8:151-161.

Klarian, S. A., C. Canales-Cerro, P. Barría, P. Zárate, F. Concha, S. Hernández, M. Heidemeyer, P. Sallaberry-Pincheira, and R. Meléndez.

2018. New insights on the trophic ecology of blue (Prionace glauca) and shortfin mako sharks (Isurus oxyrinchus) from the oceanic eastern South Pacific. Mar. Biol. Res. 14:173-182. Article

Krebs, C. J.

1999. Ecological methodology, $2^{\text {nd }}$ ed., 620 p. AddisonWesley Educational Publishers, Inc. Menlo Park, CA.

Litvinov, F. F.

2006. On the role of dense aggregations of males and juveniles in the functional structure of the range of the blue shark Prionace glauca. J. Ichthyol. 8:613-624. Article

Loor-Andrade, P., J. Pincay-Espinoza, and R. Rosas-Luis. 2017. Diet of the blue shark Prionace glauca in the Ecuadorian Pacific Ocean during the years 2013 to 2015 . J. Appl. Ichthyol. 33:558-562. Article
Lopez, S., R. Meléndez, and P. Barría.

2010. Preliminary diet analysis of the blue shark Prionace glauca in the eastern South Pacific. Rev. Biol. Mar. Oceanogr. 45:745-749.

Macharé, J., M. Sebrier, D. Huaman, and J.-L. Mercier.

1986. Tectónica cenozoica de la margen continental Peruana. Bol. Soc. Geol. Peru 76:45-77.

Markaida, U., and O. Sosa-Nishizaki.

2010. Food and feeding habits of the blue shark Prionace glauca caught off Ensenada, Baja California, Mexico, with a review on its feeding. J. Mar. Biol. Assoc. U.K. 90:977-994. Article

Mendoza-Ávila, M., G. Zavala-Zambrano, F. Galván-Magaña, and P. Loor-Andrade.

2016. Feeding habits of wahoo (Acanthocybium solandri) in the eastern Pacific Ocean. J. Mar. Biol. Assoc. U.K. 97:1505-1510. Article

Minchin, D

1996. Tar pellets and plastics as attachment surfaces for lepadid cirripedes in the North Atlantic Ocean. Mar. Pollut. Bull. 32:855-859. Article

Moscoso, V.

2013. Clave para identificación de crustáceos decápodos y estomatópodos del Peru. Bol. Inst. Mar Peru 28:8-25.

Munroe, S. E. M., C. A. Simpfendorfer, and M. R. Heupel.

2014. Defining shark ecological specialisation: concepts, context, and examples. Rev. Fish Biol. Fish. 24:317-331. Article

Nakano, H., and M. P. Seki.

2003. Synopsis of biological data on the blue shark, Prionace glauca Linnaeus. Bull. Fish. Res. Agency 6:18-55.

Nakano, H., and J. D. Stevens.

2008. The biology and ecology of the blue shark, Prionace glauca. In Sharks of the open ocean: biology, fisheries and conservation (M. D. Camhi, E. K. Pikitch, and E. A. Babcock, eds.), p. 140-151. Blackwell Publishing, Oxford, UK.

Nesis, K. N.

1996. Mating, spawning, and death of oceanic cephalopods: a review. Ruthenica 6:23-64.

Orosco-Montenegro, L. X.

2016. Variabilidad espacio-temporal de paralarvas de cefalópodos en el mar peruano entre los años 2013 y 2014. B.S. diss., 89 p. Universidad Ricardo Palma, Lima, Perú

$\mathrm{R}$ Core Team.

2018. R: a language and environment for statistical computing. R Foundation for Statistical Computing, Vienna, Austria. [Available from website, accessed May 2018.]

Rivaton, J., and P. Bourret.

1999. Les otolithes des poissons de l'Indo Pacifique. Doc. Sci. et Tech. II 2, 378 p. Inst. Rech. Dev., Nouméa, New Caledonia.

Roper, C. F. E., and R. E. Young.

1975. Vertical distribution of pelagic cephalopods. Smithson. Contrib. Zool. 209, 51 p.

RStudio.

2018. RStudio: integrated development environment for R. RStudio, Inc., Boston, MA. [Available from website, accessed May 2018.]

Sajinez, M., J. Ledesma, and J. Salcedo.

2016. Presencia del género Argonauta en el norte del ecosistema de Humboldt, asociadas a las variables oceanográficas 2009-2015. In Libro de resúmenes. V Congreso de Ciencias del Mar del Perú; Lambayeque, Peru, 
21-25 November (W. Carbajal, J. Chanamé, E. Angulo, and J. Fupuy, eds.), p. 337. Univ. Pedro Ruiz Gallo, Lambayeque, Peru.

Smale, M. J., M. R. Clarke, N. T. W. Klages, and M. A. C. Roeleveld.

1993. Octopod beak identification-resolution at a regional level (Cephalopoda, Octopoda: southern Africa). S. Afr. J. Mar. Sci. 13:269-293. Article

Sneli, J.-A.

1983. Larvae of Lepas anatifera L., 1758, in the North Sea (Cirripedia). Crustaceana 45:306--308. Article

Soberón, J., and J. Llorente.

1993. The use of species accumulation functions for the prediction of species richness. Conserv. Biol. 7:480-488. Article

Solano, A., Á. Tresierra, V. García, C. Goicochea, V. Blaskovic, B. Buitrón, and G. Chacón.

2015. Biología y pesquería del perico o dorado Coryphaena hippurus, febrero 2010. Inf. Inst. Mar Peru 42:35-73.

Spalding, M. D., H. E. Fox, G. R. Allen, N. Davidson, Z. A. Ferdaña, M. Finlayson, B. S. Halpern, M. A. Jorge, A. Lombana, S. A. Lourie, et al.

2007. Marine ecoregions of the world: a bioregionalization of coastal and shelf areas. BioScience 57:573-583. Article

Stevens, J. D.

1973. Stomach contents of the blue shark (Prionace glau$c a$ L.) off south-west England. J. Mar. Biol. Assoc. U. K. 53:357--361. Article

Stevens, J. D., R. Bonfil, N. K. Dulvy, and P. A. Walker.

2000. The effects of fishing on sharks, rays, and chimaeras (chondrichthyans), and the implications for marine ecosystems. ICES J. Mar. Sci. 57:476-494. Article
Tricas, T. C.

1979. Relationships of the blue shark, Prionace glauca, and its prey species near Santa Catalina Island, California. Fish. Bull. 77:175-182.

Vandeperre, F., A. Aires-da-Silva, J. Fontes, M. Santos, R. Serrão Santos, and P. Alfonso.

2014. Movements of blue sharks (Prionace glauca) across their life history. PLoS ONE 9(8):e103538. Article

Vögler, R., E. Beier, S. Ortega-García, H. Santana-Hernández, J. J. Valdez-Flores.

2012. Ecological patterns, distribution and population structure of Prionace glauca (Chondrichthyes: Carcharhinidae) in the tropical-subtropical transition zone of the north-eastern Pacific. Mar. Environ. Res. 73:37-52. Article

Wolff, G. A.

1982. A beak key for eight eastern tropical pacific cephalopod species with relationships between their beak dimensions and size. Fish. Bull. 80:357-370.

1984. Identification and estimation of size from the beaks of 18 Species of cephalopods from the Pacific Ocean. NOAA Tech. Rep. NMFS 17, 50 p.

Xavier, J. C., and Y. Cherel.

2009. Cephalopod beak guide for the southern ocean, 129 p. British Antarctic Survey, Cambridge, UK.

Zevina, G. N., and M. Memmi.

1981. Distribution of the pelagic barnacle crustaceans in the Atlantic ocean with respect to anthropogenic factors. In Epiboly and biological corrosion in aquatic medium (N. A. Rudyakova, ed.), p 99-109. Nauka, Moscow, Russia. 